\title{
Origins, Development, and Consolidation of the Shanghai Cooperation Organization after the Bishkek Summit
}

\author{
Lorena Di Placido *
}

\section{Introduction}

Over the centuries the history of the Central Asian states has been marked by the growth and decline of numerous empires which rotated around deserts and plains inhabited by nomads. They continued to live in distinct but interdependent communities, even though they shared the same cultural influence created by Turkish, Persian, and Islamic traditions, spoke different languages, and had different lifestyles. ${ }^{1}$

The Tsarist empire conquered the entire region through the eighteenth and nineteenth centuries and outdid Great Britain in the so-called "Great Game," a true competition between the two powers in order to obtain domination over Central Asia. The Tsar did not establish central control over the Region, but preferred to maintain a traditional form of government as long as the situation remained stable. The Soviets imposed a more incisive level of control from 1924-1936. ${ }^{2}$ The current border situation in Central Asia is the result of a choice made by Stalin, who created precise borders that were not "national" or "ethnically demarcated" (an issue still difficult to distinguish considering the composition of the area's population), but were intended to determine in each republic an artificial titular ethnic majority, a group just a little larger than the numerous minority groups who were already present. $^{3}$

Lorena Di Placido is an Analyst at the Military Centre for Strategic Studies (CeMiSS) in Italy.

1 Adrienne L. Edgar, "Identities, Communities and Nations in Central Asia: A Historical Perspective," presentation given at a panel discussion entitled "Central Asia and Russia: Responses to the 'War on Terrorism,"” held at the University of California Berkeley on 29 October 2001; at www.socrates.berkeley.edu/ bsp/caucasus/articles/edgar_2001-1029.pdf.

2 Rajan Menon and Hendrik Spruyt, "The Limits of Neorealism: Understanding Security in Central Asia,” Review of International Studies 25 (1999)

3 According to a current minority of Russian scholars, the contemporary Central Asian ethnos is not the result of ancient conflicts or population movements, but of reforms launched during the period of Russian colonization and even more during the Soviet era. This constructive approach analyzes Central Asian events by taking into consideration that, prior to the Russians' arrival in the region, nobody possessed an ethnic consciousness as it is understood today, and that there were no common categories or identities in Central Asia. Someone suggested that if a Central Asian inhabitant was to be questioned about his/her identity his/her immediate reply would be that of being a Muslim, followed by the city or region of residency; in other words, they do not perceive themselves as belonging to a specific nation or population. Such a consciousness only emerged following the artificial divisions caused by Russia. For an in-depth analysis, see Sergei Abashin, "The Transformation of Ethnic Identity in Central Asia: A Case Study of the Uzbeks and Tajiks," Russian Regional Perspectives Journal 1:2 (2006): 32-35; available at www.iiss.org. 
Those territorial delimitations that were imposed on Central Asian republics recently resurfaced with all their complexities intact right after the dismantlement of the USSR. Following the October Revolution, the best way to allocate Turkistan was debated, and this involved states such as Kazakhstan, Turkmenistan, Tajikistan, Kyrgyzstan, and Uzbekistan. Throughout the Soviet period ancient disagreements, rivalries, and patterns of inter-ethnic cohabitation remained frozen, but they dangerously reemerged in the early 1990s, when the five Central Asian republics suddenly became independent and were deprived of Moscow's tutelage. They might still have needed central protection because of the total lack of experience of the "non-Russian" populations in these new states, who until that moment had never been given any significant administrative tasks or political responsibilities. Even China and the former Soviet Republics had unresolved border disputes that resurfaced in the 1990s. They intervened with both bilateral and multilateral negotiations that led to the formation of the Forum Shanghai Five in 1996. During the Forum, they decided to tackle the inter-state border issues, not on the basis of ethnic separation and territorial partition, but on the basis of common benefit and compromise. ${ }^{4}$

This proved to be an original and significant choice for the region, to the extent that the expression "the spirit of Shanghai" was invented to define the profound novelty of this method of formulating the relations between major regional protagonists and former Soviet Republics of Central Asia - a spirit characterized by mutual trust, common advantage, equality, cooperation, respect for cultural diversity, and collective development.

Thorny issues still remain unresolved, such as the lack of border guards in some states and the presence of wide minefields in inter-state areas where interethnic conflicts are very intense. The hot-button topic of granting visas in many countries caused the closure of borders to both domestic and commercial traffic. This inheritance led to the constitution of the Shanghai Cooperation Organization.

\section{The Origins}

The Shanghai Cooperation Organization originated from negotiations held between 1991 and 1994 that initiated the settlement of the hoary disputes over the status of 4,600 kilometers of border between the Soviet Union and China.

After the fall of the Soviet Union, Kazakhstan, Tajikistan, and Kyrgyzstan (three former Soviet republics bordering on the Chinese giant) joined the table of negotiations. On 26 April 1996, Russia, China, and the three new negotiators signed in Shanghai an "Agreement to strengthen mutual trust measures on the border area," known as the Shanghai Agreement).

The signatories of the Shanghai Agreement were defined as the Shanghai Five. The agreement included measures essentially based on a drastic reduction of military activities in an area extending one hundred kilometers on both sides of the shared bor-

4 “Central Asia: Border Disputes and Conflict Potential,” Asia Report 33 (4 April 2002); available at www.crisisgroup.org. 
ders. This first meeting was followed by several others on an annual basis; the guidelines of such a particular model of regional cooperation remained rooted in a mechanism of permanent consultation.

The year 2000 witnessed several meetings held by experts from the Defense and Foreign Affairs Ministries of the Shanghai Five who worked hard to intensify the collaboration process and the effectiveness of the consultation mechanism.

The fifth summit of the heads of state, held on 5 July 2000 in Dushanbe, was clearly seen as a significant evolution of this effort. The final statement strongly emphasized the intention to transform the Shanghai Five into a regional structure of multilateral cooperation. This became necessary not only in relation to the sphere of activity but also with a view to creating more efficient and coordinated collaboration within the framework of the agreements that were already in place. The final declaration, therefore, established that each summit should be followed by meetings of heads of state and annual conferences of Ministers of Foreign Affairs. The perspective to institutionalize the Shanghai process brought about the decision to define it as a "Forum."

All members acknowledged their common willingness to fight against international terrorism, religious extremism, and national separatism which-together with criminal activities such as the illegal circulation of weapons and narcotics, as well as illegal immigration - represent the great threats to national security in the region. In order to combat these elements, they decided to take steps aimed at countering terrorist and violent activities.

As a corollary to this statement, the three Central Asian states expressed their support for China and Russia in their fights against "separatist movements," in Xingjiang and Chechnya, respectively. They acknowledged the United Nation's role as the sole global forum for the resolution of international controversies and for keeping up the principles and objectives of the United Nation's mediation cards. In consideration of the principles of equality and mutual benefit, all parties committed themselves to form a partnership covering issues related to the improvement of investment methods and providing for measures designed to resolve any disputes that might arise during the cooperation process.

On this occasion it is worth mentioning that Uzbekistan participated for the first time with observer status, and that Kyrgyzstan proposed the establishment of an antiterrorism center in Bishkek. A trilateral agreement regarding border issues between Kyrgyzstan, China, and Tajikistan was also signed. ${ }^{5}$

With the "Declaration of the Creation of the Shanghai Cooperation Organization" (henceforth, SCO) on 15 June 2001, the heads of state of the Republic of Kazakhstan, the Chinese People's Republic, the Kyrgyz Republic, the Russian Federation, and the Republic of Tajikistan welcomed the Republic of Uzbekistan as a new member of the Forum Shanghai Five and unanimously decided to transform this consolidated mechanism of cooperation into a full regional organization that would be better suited

5 Dinara A. Kalieva, Ot “Shangajskoj Piaterki” k Shangajskoj Organizatii Sotrydnicestva,” available at www.kisi.kz. 
to effectively face the challenges threatening regional security and to secure relations with extra-regional players in the fields of economics, environmental protection, and culture. Additionally, the SCO's member states signed the "The Shanghai Convention on the fight against terrorism, separatism, and extremism," reaffirming their intention to immediately establish an antiterrorism center and thus confirming their willingness to keep their commitments. Now the SCO covers an area of 32 million square kilometers, corresponding to 60 percent of the Euro-Asian landmass, with a population of about a billion and a half people, or almost a third of the global population.

On the fifth anniversary of the SCO's foundation, the entry of Uzbekistan highlighted the increasing interest that other regional players have shown toward this new form of regional cooperation, and pointed out that much is expected from multilateral cooperation in the fight against terrorism. In fact, after a period when it only had observer status within the Forum, Uzbekistan, which has suffered seriously from Islamist insurgencies, joined the group as a full member. The decision to overcome strong initial skepticism about joining the forum was influenced by the prospects of growth in the context of economic cooperation and the improvement of regional communication networks.

The SCO promotes actions aimed at the development of a new security concept, based on the principle of reciprocity and disarmament. It additionally promotes renewed relations between states based on partnership and on a new model of regional cooperation. ${ }^{6}$ The SCO's mission mostly resides in waging the war declared on the three major dangers identified by the member states: Islamist terrorism, religious extremism, and national separatism.

In spite of all the efforts spent to obtain an effective instrument through the SCO to respond to the common threats and to improve the general conditions of all member states, numerous observers have considered that these cooperative efforts were nothing more than an attempt by Russia and China to exclude the United States from the "Great Game" that has been reopened in Central Asia, and to mask this ambition through a regional initiative with a multi-polar façade. Therefore, "minor" members have no other option but to join and hope to exploit this position for their own future advantage.

According to other observers, this initiative is a response to the growth of Western influence in Central Asia, rather than to a security threat coming from Afghanistan or from a joint force of Chechens, Taliban, and Uighurs, and is therefore meant on the one hand to compensate for the decline of Russia's influence in the region and on the other hand to meet China's security needs in the area across its western borders. ${ }^{7}$

Some analysts suppose that this could become a forum to meet the interests of Russia and China in the context of mutual containment or even integration into the Central Asian Cooperation Organization (CACO). ${ }^{8}$ On the contrary, other experts believe that

See www.sectsco.org.

“Shanghai Cooperation Organization Established,” Monitor 7:120 (22 June 2001); available at www.jamestown.org.

8 Farkhod Tolipov, "On the Role of the Central Asian Cooperation Organization within the SCO,” Central Asia and the Caucasus 3 (2004); available at www.cacianalyst.org. 
the SCO satisfies the national interests of all members and not only those of the major states, since it resolves border disputes between all member states in addition to recognizing their common fight against religious extremism and Islamist terrorism. The SCO includes two members of the United Nations Security Council that could give voice to Central Asian interests, and it also opens new collaborative possibilities in the social and economic spheres. At any rate, the strengthening of regional cooperation does not create the conditions for a clear and irreversible closure of Central Asia to the West, since all Central Asian nations rely on vital foreign investments.

The first steps towards integration started in the year 2001. On September 14 of that year, the heads of state who met in Almaty signed a memorandum on "The principal aspirations and tendencies of economic ties in the Region," whereby they created a mechanism of ministerial consultations in the commercial and economic sphere and set up working groups to deal with various cooperation processes. Considering the fact that they met just after the events of 11 September 2001, the heads of state adopted a joint declaration that strongly condemned the terrorist acts against the United States, and confirmed their full preparedness to cooperate with other states and organizations to combat this new global threat. ${ }^{9}$

\section{Development and Consolidation}

In the years 2002 and 2003 the foundation was laid for the realization of the Organization's complete structures. On the occasion of the St. Petersburg Summit, held on 7 June 2002, SCO members signed the "Shanghai Organization Paper," with which they clearly expanded the principles and the methods of operation of the SCO, both on the international scene and in regional cooperation. This agreement strengthened mutual trust and neighborly ties between member states and set out frameworks for enhanced cooperation in political affairs and in a number of other fields such as economy, commerce, science, technology, energy, transportation, environmental protection, peace, culture, security, and stability. The document was dedicated to the promotion and creation of a new international order based on democracy, justice, and rationality. Increasing the institutional focus of the SCO did not, however, lead the member states to neglect their commitment to combat terrorism, which culminated in the multinational military exercises known as Cooperation 2003.

The General Secretariat in Beijing and the Regional Antiterrorism Center in Tashkent both became operative on 1 January 2004. The director of the Study Center for the Shanghai Cooperation Organization recognizes these institutions as containing many important instruments to manage both ordinary and emergency issues: once the historic border issues were resolved, the level of cooperation deployed to fight against the "three evil forces" was intensified, first of all by paying more attention to Afghanistan and then by announcing a new campaign against drug trafficking in the region. The non-definitive disappearance of the Taliban together with the 2004 terrorist attacks

9 Dmitri Trofimov, "Shanghai Process: From the 'Five' to the Cooperation Organization. Summing up the 1990s and Looking Ahead,” Central Asia and the Caucasus (2002), Centre for Social and Political Studies (Sweden). 
in Uzbekistan followed by the attacks on Chinese workers in Afghanistan reinforced the necessity to coordinate antiterrorism initiatives by the SCO nations with all the efforts already active in Afghanistan.

During the Tashkent Summit, Russia's President Vladimir Putin proposed and obtained the establishment of an SCO-Afghanistan Contact Group in order to promote initiatives aimed at reconstruction, peacekeeping, and the fight against terrorism in the context of a "Cooperation Agreement between SCO Members for the fight against narcotics." Following this path, all the member nations supported Uzbekistan's initiative to keep regular meetings with the Organization's General Secretariat in order to enforce anti-criminal and antiterrorist cooperation efforts at maximum levels.

\section{Potential New Admissions}

During the annual summit of heads of member states held in Astana on 5 July 2005, and at the conclusion of a biennial summit devoted to the consolidation of the SCO's institutions, the improvement of the Organization's prestige, the development of external relations, and the reinvigoration of commercial ties, the members launched a cooperation mechanism on the basis of regional participation. They accepted new observerstatus members, such as Iran, India, and Pakistan and thus projected themselves on one side towards the greater Middle East and on another towards the emerging Indian subcontinent.

In recent years, the initiatives launched under the "spirit of Shanghai" attracted the attention of many international actors, and an increasing number of nations and organizations have sought to restore contacts with SCO member nations, to the extent that on the occasion of the Council of Foreign Ministers in November 2002, a "Scheme of the Relations between the Shanghai Cooperation Organization and the other States or International Organizations" was adopted, which formally launched the program of external relations with the SCO. This program provides for guest participation in the meetings of the Council of Foreign Ministers and in diplomatic consultations on a reciprocal basis.

In 2003, SCO representatives participated in several special sessions of the United Nations Security Council Antiterrorism Committee. The SCO's relationship with the United Nations seems to be a privileged one; in fact Kofi Annan, then the UN Secretary-General, attended the inauguration ceremony of the Beijing General Secretariat on 15 January 2004: he expressed appreciation for the progress achieved in regional security, and did not hesitate to define the Organization as a strategic partner. At his invitation, the SCO General Secretary Zhang Deguang participated as an observer in the UN General Assembly for the sixtieth anniversary of the United Nations (14-16 September 
2005), where he delivered a celebratory speech. Additionally, the SCO has concluded agreements with ASEAN, ${ }^{10}$ with the CIS, and with Interpol. ${ }^{11}$

Prior to the admission of new members, the Organization decided to allow itself an additional period of rest and consolidation, and it also succeeded in obtaining a regulation of the status of observers at the Tashkent Summit of 2004. Today, by considering Iran, India, and Pakistan, the Organization has definitely reached a high level of quality and, following its first contacts with Mongolia in 2004, it confirmed its commitment to high-profile regional cooperation, which encompasses expanding the space for a coordinated antiterrorism action towards the greater Middle East and projecting itself into South Asia in pursuit of new trade channels. This evolutionary process attracted the interest of Turkey, Afghanistan, and Japan, who asked to be admitted as new observers as soon as possible. ${ }^{12}$

\section{Antiterrorism Coalition Bases in Afghanistan}

The Astana Summit provoked a certain debate due to the final declarations made by the various members regarding the antiterrorism coalition operating in Afghanistan. In these declarations, they requested that a final date be set for the temporary use of the land and air space infrastructures that were originally conceded solely for the limited amount of time necessary for the ongoing stabilization operations in Afghanistan.

This request was expressed in the context of considerations related to special economic and social assistance programs desirable for Afghanistan, which is still at the crossroads of a flourishing traffic of narcotics. Regional experts have generally detected in those statements a desire to expel the United States from countries that host U.S. troops on their territory and the consequent alignment of these countries with the positions of the major regional powers (Russia and China). It is most probable that the latter may have inspired these declarations with the intention to contain the U.S. presence in Central Asia, and thus to reaffirm their own influence in the area. They also

10 On 21 April 2005, General Secretary Zhang Deguang met with ASEAN General Secretary Ong Keng in the Secretariat headquarters of Jakarta. The organizations are geographically contiguous, and they share common interests in the Pacific area; this is how they decided to establish cooperation in several sectors for their mutual advantage, by creating forms of interaction through an Agreement Memorandum subscribed during that occasion. The ASEAN General Secretary also expressed his desire to obtain the status of a Shanghai Organization Observer. For in depth analysis, see www.sectsco.org.

11 Through an invitation by the Interpol General Secretary, the Assistant Manager of the Executive Committee of the Regional Antiterrorism Structure participated in the group workshop on the "Kalkan" project regarding the theme "Terrorism in Central Asia," which was held in Almaty and was organized by Interpol and the Kazakhstan Ministry of Internal Affairs. They discussed cooperation methods, since both institutions are committed in gathering information and coordinating both preventative and responsive anti-terrorism activities. For in depth analysis, see www.ecrats.com.

12 Pan Guang, "The New SCO Observers: Making a Leap Forward in Cautious Augmentation," CEF Quarterly-The Journal of the China-Eurasian Forum (July 2005); available at www.chinaeurasia.org. 
benefited from the unsettled mood caused in Uzbekistan by Washington's criticism of the Uzbek regime's harsh repression of the Andijan disorders: following the U.S. request to allow an independent commission to investigate the May events that were considered by Tashkent as an appropriate response to an insurrection by terrorist groups, the Uzbek government replied by a letter dated July 29, in which it gave the United States a period of 180 days to withdraw its forces (about 800 troops) from the base of Kharshi-Khanabad.

Consequently, the U.S. Secretary of Defense, Donald Rumsfeld, declared that military operations in Afghanistan would continue, given the persistence of the Taliban forces, along with elements with Al Qaeda. Meanwhile, military experts worked to identify new options for continuing these military operations, as well as for providing support for humanitarian efforts in Afghanistan. According to Rumsfeld, the bases in Central Asia have been extraordinarily useful in supporting the antiterrorism coalition that has been active in combating terrorism as well as drugs trafficking. ${ }^{13}$

The United States has so far paid Uzbekistan USD 15.5 million for the use of the base for a period of time that ranged between October 2001 to December 2002, and is still due to pay the sum of USD 23 million for the period from January 2003 through December 2005. The payment was halted right after the bloody repression of the Andijan uprising.

Faced with certain statements that were scarcely compatible with the behavior of Tashkent, China declared its intention to invest in Uzbekistan; it even sympathized with the way this country had behaved during the Andijan clashes, which was considered by China as a lesson that demonstrated the necessity of not giving in the fight against terrorism. The Russian Defense Minister Ivanov declared his intention to include technical and military assistance to Kyrgyzstan in the Russian Federation's budget, to hold joint antiterrorism exercises in 2006, and to maintain the commitment to improve the infrastructures of the Kant base currently used by Russian troops stationed in the country. ${ }^{14}$

The behavior of the Central Asian states does not seem to be bound by the Declaration of Astana which, however ambiguous it may appear, only focuses on the base concession issues, programmatically leaving to the members' initiative "if" and "how" to proceed, and thus giving free rein to the political independence of each state as far as operationalizing the common vision is concerned. Uzbekistan, therefore, prefers to safeguard its own regime by maintaining its status quo in the region (this has been repeatedly emphasized by reference to the shared principle of non-interference into the internal affairs of the Shanghai Cooperation Organization member states) and waits for

13 In March 2002, Uzbekistan President Karimov made his first official visit to U.S. The two countries formalized a bilateral agreement: the United States offered economic support that would have guaranteed (together with institutional reforms) a concrete commitment against the Islamist terrorist threat. See "Historic Visit," at http//2004.press-service.uz. See also "U.S. Still Welcome at Manas Air Base."

14 Roger McDermott, "Russia Offers 'Quality' Military Assistance to Kyrgyzstan,” at www.jamestown.org. 
the consolidation of investments of a regional nature instead of benefiting from those already offered in the form of U.S. financial support which is, politically speaking, potentially more "onerous," considering that it is conditional upon the realization of democratic reforms.

\section{The Shanghai Summit: The Results of Five Years of Activity and the Perspective of Consolidation and Cooperation with Observer Countries}

Five years after its birth, the SCO held its annual summit in the city of its foundation in an atmosphere of great celebration. In addition to the presidents of the six member states, the summit included the participation of the Organization's leaders (Secretary General Zhang Deguang and Viaceslav Temirovic Kasyanov, director of the RATS executive committee), as well as representatives of the observer countries, ${ }^{15}$ the CIS, and ASEAN. $^{16}$

This attendance significantly describes the path adopted so far by the SCO, as the representatives of observer states expressed their desire to be admitted in the near future as full members. Therefore one can witness on the one hand the increasing regional interest in the Organization, and on the other hand the possibility to project this successful model of cooperation beyond the strictly Central Asian geographic context.

At this point there is a situation in which self-concerned regimes use the instrument of a cooperation model to favor the maintenance of the current regional balance and to exclude the possibility of any sort of intervention by third parties. This aim is expressed in the Astana Declaration, where the principle of safeguarding the status quo is particularly emphasized to the detriment of promoting "regional opening." One can predict a phase of additional consolidation of the institutions and ties between current member states who have already established privileged relations with some organizations related to Asia and Central Asia and have attracted the interest of other regional players who in the future could become new SCO members.

Putin advocated the constitution of an Energy Club within the SCO context, and announced that his country is evaluating the possibility to finance development projects in the field of energy as well as in transportation and communication. Even if their contents are still vague, these proposals seem to represent a reply to the generous

15 The following participated as observers: Shri Murli Deora, India's Oil and Natural Gas Minister; Mahmud Ahmadinejad, President of the Islamic Republic of Iran; Nambaryn Enkhbayar, President of Mongolia; Pervez Musharraf, President of the Islamic Republic of Pakistan; and Hamid Karzai, President of the Islamic Republic of Afghanistan.

16

The United Nation Secretary General sent his congratulations to the participants of the Shanghai Summit for their profound engagement and the results obtained throughout the first five years of life of the SCO, ever since its first steps like the Shanghai Forum up to actions taken in regard to their most cherished interests for international reality. Kofi Annan anticipated the SCO's participation in the UN's next summit with regional and intergovernmental organizations; see www.scosummit2006.org. 
Chinese investments that were formalized during the summit, in a context in which Russia could want to again play a key role in the Central Asian "near-abroad." "17

The fact of belonging to the "club" of energy supplier countries has two facets: on the one hand, it represents an element of proximity, which creates a common space of economic interest between Russia and the Central Asian republics; on the other hand, it gives rise to a situation of competition between suppliers vis-à-vis the complementary Chinese economy, a producer of low-cost consumer goods and technological knowhow. During this phase it seems that a certain Chinese "advantage" in relations with its Central Asian partners has been consolidated. This was also confirmed by China's generous financing of a series of development projects. According to some observers, closer ties with China could lead to the transformation of Central Asian culture into a Chinese culture; this "threat" is particularly felt in countries that have common borders with China.

The Shanghai Summit produced a regulatory framework with provisions for the admission of new members but it did not make, for the time being, any decisions regarding new entries. All observer states have asked to become full members of the Organization, but current members believe that the time is not yet ripe to expand the composition of the SCO. In fact, there are ongoing important changes in institutions destined to reinforce the participation of all national components and assure continuity in the stabilization process. Important projects regarding the economy are under study, while others are under development: this will certainly boost the aspect of economic cooperation that has always been emphasized in words, but is only now beginning to be concretely implemented.

Another target not to be underestimated concerns the privileged bilateral relations that all observers have had so far with China, which has been a key economic partner of extraordinary importance and whose role continues to grow constantly in the region. It seems that the prospect of participating in a project of regional organic development led by the most dynamic economic partner in that area accounts for the interest expressed by current observers in joining the SCO.

Consequently, if on the one hand the Organization continues its cautious political approach when it comes to admitting new members, on the other hand it has expressed the will to immediately launch a privileged relationship of strong cooperation with observer countries. Probably one has to consider that it might have been provocative to admit new members at a time when the Iranian decision to acquire nuclear technology is causing criticism and preoccupations; Iran's application to be admitted to the SCO in Spring 2006 has met with lively responses. ${ }^{18}$

The U.S. government strongly criticized Russia and China for accepting the presence of a "terrorist state" at such an important summit, as this was considered to be an infringement of the Organization's declared commitment to fight against terrorism. The

17 Vladimir Putin, Speech at the Shanghai Cooperation Organization Council of Heads of State, available at www.kremlin.ru.

18 “Iran Hopes to Join Shanghai Group This Summer,” at http://english.people.com.cn, 15 April 2006. 
possibility for Iran to become a full member of the SCO was heavily scrutinized, but very few analysts have considered the Iranian potential membership as an aspect of the enlargement issue tout court. Iran is undoubtedly the observer nation that attracts the most attention, and therefore its application for full memberships causes doubts and perplexities regarding the Organization's true nature: Is it an anti-Western alliance? A protective block of governments that promote terrorism? A combination of oil and gas producers sustained by the country most in need of energy for its own economic growth? Nonetheless, the attitude of caution that has been so often adopted regarding the expansion issue could be particularly justified now, in view of the extraordinary consequences that the Iran case is likely to bring about in terms of image and credibility when compared to the proclaimed principles that inspired the Organization.

The potential admission of Iran drove out of sight the issue of expansion with regard to observer nations in general; expanding the membership to include Iran would have unavoidably opened the SCO doors for other observers, since there would have been no reasons to keep them out if such a troublesome neighbor as Iran had been allowed in. Such a situation would have opened a new scenario: the Organization would have had an extraordinary expansion, and its tremendously expanded human and geographic dimension would have imposed an original and extraordinary strategic challenge that would have required a serious debate about maturity, solidity, stability, and equilibrium among the members.

First of all, the SCO needs some more time to stabilize itself before admitting new members. Moreover, participation in a privileged dialogue with the SCO makes observers already part of the increasing growth of the Eurasian area. Thus, enlargement is not a pressing issue either for observers or for member states.

\section{SCO: A Mirror of the Central Asian Dimension in Russian-Chinese Relations}

The SCO represents a privileged observatory from which one can look at the nature, the modalities, and even the tone of bilateral relations between Russia and China. Each of these two countries has its own "Central Asian dimension." For Russia, it is characterized by a "near-abroad" perceived as the legacy of centuries of domination-first tsarist, then Soviet, and finally Russian. In the case of China, it has a vast territory extending into the heart of Central Asia, the Xinjiang Uighur, the westernmost and among the poorest areas in the country, and one that is badly in need of urgent industrial investment and of effective measures to counter the separatist movement in Eastern Turkestan. And it is in its "Central Asian dimension" that China finds the reasons to continue (in the context of the SCO) to pursue its economic, energy supply, and security interests, all of which are considered essential for its western province to become a flywheel for the development of the whole country.

Central Asia's energy resources are of huge interest to China, which is undergoing economic development of enormous momentum. This is why the fight against terrorism, separatism, and extremism; the preservation of safe borders and regional stability; and the pursuit of joint economic development initiatives and friendly relations with 
Central Asian states (keeping the latter safe from the influence of hostile powers or military alliances) are considered to be preconditions for regional security to become a factor in the security and development of China. For its part, China offers its Central Asian partners not only cheap commodities but also, and most importantly, infrastructure investments and a mutually beneficial commitment to the maintenance of regional stability. ${ }^{19}$

The quick growth of investments and commercial relations has opened the borders between China and the Central Asian countries, restored the route of the old Silk Road, and revived links and interconnections that are vital for both Central Asian economies and for China's underdeveloped western provinces. The establishment of such important economic ties leads to better political, legal, and social relations in the region, and thereby enhances political compatibility and stability not only at the bilateral level, but also for the benefit of the whole region. ${ }^{20}$

China recognizes Central Asia's strategic importance and its potential impact on global events, and it understands the role the region can play as a gas and oil supplier in its own economic development. China is eager to avoid scenarios in which Central Asian countries might evolve towards situations detrimental to Chinese interests by giving birth to radical governments. Most important, it recognizes that a multilateral approach is a useful instrument to achieve common interests, and it considers the region as a trans-continental bridge not only from a geographic but also from a cultural and political viewpoint. ${ }^{21}$

High levels of interaction among the peoples of the area have existed for centuries, and have often been accompanied by territorial, religious, national, and water utilization disputes. At present the situation is apparently becoming stabilized, but some instability factors are still present that might turn out to be prejudicial to Chinese interests, mainly in the field of security. But Central Asia attracts the interest not only of China, but also of various regional powers (Russia, India, Iran, and Turkey) and of powers of regional relevance (United States, European Union, Japan). The new security balance in the years to come will be dependent on the mutual relationships between all these actors.

China is dependent on oil imports from Central Asia to secure its economic development. In 1997, China imported 35.47 million tons of oil, and doubled that figure after five years, when it imported 69.40 million tons; in 2003, Chinese oil imports reached 90 million tons, and in 2004 they were over 100. As China clearly depends on foreign sources for its energy supply, 50 percent of which comes from the Middle East

19 Zhao Huasheng, “Kitaj, Tsentral’naija Azija i Shanhajskaja Organizatsija Sotrudnicestva,” Moskovskij Zentr Karnegi, Rabocie Materialy 5 (2005).

20 Niklas Swanström, “Chinese Business Interest in Central Asia: A Quest for Dominance,” 2003, at www.cacianalyst.org.

21 Adiljon Umarov and Dmitry Pashkun, "The Prospects for Chinese Influence in Central Asia," CEF Quarterly-The Journal of the China-Eurasia Forum (February 2005), at www.chinaeurasia.org. 
and 22 percent from Africa, it has now opened a new flow from Central Asia in order to diversify its sources. ${ }^{22}$

This new trend is still subject to a number of constraints both on the Chinese sidewhere the interests of Beijing's politicians and those of the state-run oil companies sometimes diverge, and at times have to take into account the latter's limited financial resources - and on the Central Asian side, due to the fact that the government-owned oil industries have been left with the infrastructure (pipelines, roads, railroads) they inherited from the Soviet period, which were designed to serve only Russia, and are therefore unsuitable for the new trade flows. At present it would be incorrect to consider Central Asia as an integral part of a consolidated supply system; what can be said, in view of the investments being made, is that it is a medium/long-term goal. ${ }^{23}$

From an economic and energy supply viewpoint, China has fruitful bilateral relations primarily with Kazakhstan and Uzbekistan, the two largest Central Asian countries. The Kazakh Embassy in China reports that in 2003 the volume of trade between the two countries accounted for USD 3.29 billion-i.e., 68 percent more than the previous year, with a growth outlook of USD 5 billion by $2010 .^{24}$ Against these rosy prospects of mutual economic advantages there are still a number of unsolved issues related to migration flows and the utilization of water resources; these issues, however, do not affect the importance of bilateral relations between Kazakhstan and China, which concern:

- Border security

- Counterterrorism efforts

- The prospects for strengthening and expanding energy imports to meet China's fast growing demand.

More recently the two Asian giants, Russia and China, have undertaken a fruitful bilateral cooperative effort in the aerospace and satellite field. Beijing has announced that it will launch its first scientific research satellite, and wishes to participate in joint projects with Moscow. The satellite, which is planned to be launched in 2010, will carry an X-ray modulation telescope developed by Chinese scientists to investigate black holes and other space phenomena. Moreover, China will participate in the Russian project to send a remote-controlled shuttle to Phobos, a satellite of Mars, to gather material from the ground of that celestial body.

China, which at the beginning of 2007 already possessed an excellent anti-satellite missile capability, will be spending USD 45 billion on the defense sector in 2007—an

${ }^{22}$ China Energy Database (Berkeley, CA: Lawrence Berkeley National Laboratory, June 2004); available at www.china.gov/china_policy-ced.html.

${ }^{23}$ Kevin Sheives, "China and Central Asia’s New Energy Relationship: Keeping Things in Perspective," CEF Quarterly-The Journal of the China-Eurasia Forum (February 2005), at www.chinaeurasia.org.

24 “Crescono gli interessi di Pechino nell’Asia Centrale,” 5 July 2005, at www.asianews.it. 
18 percent increase over the previous year-which is a matter of no little concern for many American politicians. ${ }^{25}$

Russia, for its part, having settled all territorial issues with China in the Far East, has no intention to discontinue its huge military spending. Its military procurement budget has risen from 16 billion Euros in 2005 to 19 billion in 2006 and the destinations of its defense-sector exports are the same as the former USSR's: India, Malaysia, Pakistan, the Arab world and, as a new entry, China. The 3000 firms classified as strategic at the end of the past century have been reduced to 1059, and out of these 700 have been privatized. The Russian state, however, has retained a large share of control: it has full control over 21 percent of Russia's aircraft companies, 35 percent of its ground armaments firms, 40 percent of the shipbuilding sector, 54 percent of missile industries, and 82 percent of munitions firms. This actually precludes joint ventures, since non-Russian subjects are prohibited by law from owning more than a 25 percent share in a firm that is considered to be strategic. Moscow continues to deploy Topol-M intercontinental missiles, the ones NATO calls SS-27s, and hundreds of firms work in the missile sector. The aircraft industry is still very powerful as well; Russia's aircraft engine production capacity equals that of the rest of the world as a whole, and the cost of labor is very competitive as compared to the West's, which is three times as much. ${ }^{26}$

As a matter of fact, China and Russia have never been closer. Trade between them has grown by 15 percent over the past 12 months, and has reached an annual level of USD 33 billion. During a visit to Moscow by the Chinese president in late March 2007, twenty-one contracts were signed, totaling USD 4 billion. As far as energy is concerned, Russia has undertaken to supply Beijing in 2007 with fifteen million tons of crude oil by railroad while waiting for the construction of an oil pipeline and two gas pipelines which it plans to undertake before long to send Russian oil and gas to China. ${ }^{27}$

The regional scenario has been witness since 2001 to the massive presence of the United States, which has undertaken its global war on terror by focusing primarily on Afghanistan. I share the view of those who believe that the presence of the three great powers in Central Asia is not a factor of inevitable instability or of predominance, where the supremacy of one would annihilate the other, but rather a form of a balance of power, where each actor counterbalances the expansion of the other and where any unilateral initiative automatically generates deterrents and counterweights. ${ }^{28}$ What may appear as disadvantages or potential threats might on the contrary conceal forms of mutual benefit if not of cooperation, unintentional but eventually beneficial.

25 Finlay Lewis, “To Hunter, China is Cause for Alarm,” San Diego Union Tribune (11 March 2007). USA often accuse China that official Chinese defense budget is much less than the real expenditure.

26 Antonio Missiroli and Alessandro Pansa, “La difesa europea,” Ed. Il Melangolo (2007).

27 "Firmati al Cremlino 21 contratti per un valore di 4 miliardi di dollari," Osservatore Romano (29 March 2007).

28 Murad Esenov, in the essay The Anti-Terrorist Campaign and the Regional Security System, supposes an unspoken agreement on the balance of power in Central Asia; www.ca.c.org. 
If we change our point of view, we can say that the massive entry of the United States into Central Asia can be considered as an extremely favorable event for the region, as it has put an end to the Taliban regime and thereby weakened the Islamist terrorist movements that acted within its orbit, among which were the groups of East Turkestan. At the same time, Russia and China, by sharing the common goal of containing U.S. influence, might find new bases for cooperation by focusing their relations on their mutual benefit rather than on competition. The Shanghai Cooperation Organization, whose members have chosen to focus on common general principles shared by everyone and put aside any controversial matters, seems to be the most suitable forum in which Russia and China might pursue such efforts. Thus, while coordinating their efforts to check the U.S. presence in the region, China and Russia might strengthen their bilateral relations as well as their ties with the Central Asian states, and this would be a result of the balance of power.

The joint communiqué released on 3 July 2005 after an official visit to Moscow by the Chinese president serves to confirm the analysis above. ${ }^{29}$ In this document, the two parties recognize their bilateral relations as a priority of their foreign policy, and they espouse a fundamental interest of the two countries in terms of preserving peace, stability, and regional development and contributing to global prosperity.

Particularly ambitious are the goals set for economic cooperation, which accounted for USD 21.23 billion in 2004, with a growth trend of 20 percent in 2005, and the final target of reaching USD 60-80 billion dollars in 2010. An Investment Promotion Conference was held in St. Petersburg in June 2005, where many agreements were signed on investment projects for large and medium-scale enterprises. Special attention was devoted to the strategic exploitation of Siberia's energy resources to the mutual benefit and for the promotion of the Russian Far East, Siberia, and the northwest region of China.

Russia's interest in the SCO is witnessed by a statement made by Vladimir Putin during his address to the Federal Assembly of the Russian Federation on 26 April 2007. The President encouraged Russia to promote processes of economic integration among CIS countries, and particularly with those of the Euro-Asian area. In this context, reinforcing integration and the synergies of EURASEC and the SCO is of crucial importance since, as Putin said, "this is one of those cases where economy means security, the security of our borders." ${ }^{30}$ And here the reason for the founding of the SCOi.e. safe borders - appears again to give new impetus to Russia's relations with the Euro-Asian region, bringing a message which is still valid and relevant.

\section{SCO’s Military Counterterrorism Activities}

The joint counterterrorism exercises planned by the Organization almost every year prove that there has been a qualitative leap in its coordination of military forces. The

29 “China-Russia Communiqué,” CEF Quarterly (July 2005).

30 Vladimir Putin, Annual Address to the Federal Assembly, Moscow, 26 April 2007; available at www.kremlin.ru. 
first exercises took place on 11-12 October 2002, and marked the beginning of the SCO's actual counterterrorism campaign. China and Kyrgyzstan participated in the exercises, although they both remained within their national borders. Some observers were so favorably impressed as to predict a growing role of the military dimension in the counterterrorism campaign within SCO. ${ }^{31}$

In August 2003, the first exercises took place in which five of the six member countries participated, sending both troops and observers. The goal was to improve the Organization's capacity to intervene as a reaction to a terrorist attack. Apart from the success of the initiative, known as Cooperation 2003, it is worth noting that for the first time China invited foreign troops to enter its territory. Organization members participated in joint military maneuvers as well as in the intelligence and command activities. Over 1300 men participated in the counterterrorism exercise across the Sino-Kazakh border. The exercises were organized in two stages. The first was meant to improve the command and control system. Participants included over 500 men belonging to Kazakh air defense units, as well as a Kyrgyz assault and reconnaissance platoon and a Russian motorized artillery company. During this stage, China and Tajikistan had observer status. As far as the latter was concerned, it was still suffering from the economic consequences of its civil war and had been unable to make troops and equipment available.

The second stage of the exercise was conducted on Chinese territory in the Autonomous Region of Xinjiang Uighur. The operation-designed to counter the entry into the country of one hundred separatist militants - was led by the Chinese, with the participation of Kyrgyz special forces. These training exercises were at the same time a first step towards a more effective fight against the terrorist threat in the region and a new attempt to coordinate local forces as an alternative to U.S. forces, which had entered the region at the outset of the global antiterrorist campaign and had been supported by the Central Asian republics, which had made available military bases in Uzbekistan and Kyrgyzstan and, as far as Kazakhstan was concerned, had participated in the Steppe Eagle 2003 operations with NATO in the days just before the SCO exercises. ${ }^{32}$

Chinese military sources declared that it was their intention to share with Russia, Kyrgyzstan, Tajikistan, and Kazakhstan their experience in combating terrorism, and that they were willing to agree on a shared approach against the common threats to regional stability. These training exercises were the first opportunity for the People's Liberation Army to work closely with foreign military structures, thus promoting understanding, cooperation, and development with the other member states. ${ }^{33}$

In the opinion of some observers, the joint exercises have marked a turning point in the development of the Organization, which has thus acquired an increased stature in

31 Pan Guang, "Shanghai Cooperation Organization in the Context of International Antiterrorist Campaign,” at www.ca-c.org.

32 Malia K. Du Mont, “Cooperation 2003: Style, Substance and Some Surprises,” CEF Monthly (September 2003), at www.chianeurasiaforum.org.

33 “SCO Launches Joint Exercise,” at www.china.org.cn. 
the region and a heightened credibility outside Central Asia; in addition, the SCO has gained confidence in its own abilities. ${ }^{34}$ Despite the success of the joint operations and the shared recognition that threats to regional security should be faced by using the military if need be, Russian Defense Minister Ivanov stated that the Organization is not intended to be transformed into a military bloc. ${ }^{35}$

Joint Sino-Russian exercises, named Peace Mission 2005, were conducted in the Shandongh Peninsula between 18-25 August 2005. Russian observers praised this event; they pointed out that not only were they an immediate success for bilateral relations, but that they also held promise for regional stability in the context of the SCO. According to Russian observers, Russia attached to these exercises a dual significance: on the one hand, they were meant to advise the United States as to the potential of a possible military alliance between Russia and China, and on the other they certified Russia’s presence in its own "Far East."36

The exercises involved 1800 Russian and 8000 Chinese troops, and involved a counterterrorist operation involving the Army, the Navy and the Air Force. Some observers have pointed out that probably, since no terrorist group is known to possess ships as yet, the reasons for the exercises were not solely limited to coordination purposes as declared. ${ }^{37}$ Actually, the Peace Mission 2005 exercises have reasserted that a special bilateral link exists between Russia and China with a view to containing the U.S. presence in Central Asia and to protecting the region from "colored revolutions" induced from outside.

Although they were only bilateral, these exercises have had amplified effects with respect to the other SCO partners, as they evidenced a high level of military understanding between the two main regional powers, as well as their capability to guarantee regional security and attract new partners. ${ }^{38}$ Joint counterterrorism exercises named Vostok Anti Terror 2006 were conducted in Uzbekistan in 2006 within the framework of RATS. The scenario concerned the protection of the Tashkent Nuclear Physics Institute, which hosts a nuclear reactor. This target had already been indicated by the United States as highly vulnerable. Considering the instability that had characterized the Andijan region the year before, it was thought advisable to give special attention to this vulnerable research institute; the purpose was, according to some observers, to

34 Roger McDermott, "Shanghai Cooperation Organization Takes Significant Step Towards Viability,” 9 May 2003, at www.eurasianet.org.

35 “SCO Needs Military to Fight Regional Terrorist Threat-Official,” 18 April 2006, available at www.rian.ru.

36 “Russian and Chinese Defense Ministers Praise Joint Military Exercise,” RFE/RL 9:161, Part I (25 August 2005).

37 Eurasia Daily Monitor 2:162, at www.jamestown.org.

38 “The Significance of Sino-Russian Military Exercises," 14 September 2005, available at www.pinr.com. 
strengthen the RATS intervention capacity so as to be able to tackle any emergencies that may occur as a result of U.S. troops leaving the region. ${ }^{39}$

Joint military exercises are planned to take place in the Chelyabinsk region in August 2007. Participation will involve some 4000 troops, from all services. Russia will send 2000 men and China 1600, whereas the other SCO member countries will send groups of 50 to 100 soldiers each. $^{40}$

\section{Some Considerations after the Bishkek Summit}

Due to the growing economic influence of China and India, the difficult interaction between Russia and the West, the great interest in Central Asian resources, the Afghan drama, and the region's role as a transnational crime nexus, the SCO's evolution is becoming one of the most useful keys to interpret Central Asian trends. At the last heads of state summit (held on August 16, 2007 in Bishkek), the Shanghai Cooperation Organization more and more evolved in importance and geographic scope. Its members are real economic and political powers (both at the regional and global level), and the Organization is establishing a wide network of cooperative ties with the most influential international and regional organizations. Given this, we should consider as a "pending question” among SCO members the admission of new full members while, from the Western point of view, it is of basic importance to consider a possible dialogue or even partnership with the SCO. So far, only Western organizations such as the European Union and NATO have not yet established any kind of cooperation with the SCO.

An initiative effecting that direction was taken by the German Presidency of the European Union, which organized on 3 April in Berlin an international conference entitled "Shanghai Cooperation Organization: EU Partnership Opportunities." Participants included the SCO Secretary General Bolat Nurgaliev, the EU Special Representative for Central Asia Pierre Morel, experts from SCO countries, and German scholars and politicians. This initiative had the effect of paving the way for possible cooperation between the EU and the SCO (which might lead to the EU acquiring the status of dialogue partner). ${ }^{41}$ On the other hand, the way this dialogue has been launched makes it too dependent on Germany's unilateral wishes. Germany has long been conducting an active bilateral policy towards Central Asia, and its over-exposure in this initiative creates stronger links with Berlin than with Brussels.

Energy has been one of the core topics of the meetings between European Union and Central Asian countries held during the German tenure in the EU presidency. Due to the strategic relevance of the Eurasian region, the fight against terrorism in Central

39 Nicklas Norling, “RATS Exercise in Tashkent: Concern Over Nuclear Terrorism?,” available at www.caianalyst.org.

40 Silk Road Studies Weekly Newsletter, 23 April 2007, at www.silkroadstudies.org.

41 “Berlin Hosts International Conference 'SCO: EU Partnership Opportunities,'” available at www.sectsco.org. 
Asia, and the great interest in energy supplies, the EU raised its level of commitment in Central Asian matters. ${ }^{42}$

The energy matter is now fully included in the SCO's internal debates. The constitution of a SCO Energy Club was widely debated during a round table held in Tashkent on 27 February 2007, aiming toward the development of a SCO Energy Club model and concept. This initiative was carried out only few months before the agreement among Russia, Kazakhstan, and Turkmenistan regarding joint exploitation of the Caspian Sea gas supply. If this kind of agreement also became part of the SCO's activities, the organization would have in its membership both the main energy exporting countries and one of the main consumers, China (this point is even more strongly drawn when one considers that the whole SCO space, including observers, such as Iran, includes additional energy producers, but also adds India among consumers). Thus, the organization would have continental monopoly over energy supplies, with huge ramifications for the global energy market.

For its part, NATO has just recently examined the possibility of some form of dialogue, though low-profile, with the SCO. ${ }^{43}$ A rapprochement process between the two organizations would require overcoming a purely Atlantic logic in order to reach the pragmatic consideration that the Euro-Asian region is bound to be a protagonist on the international stage in the years to come, and that NATO cannot exclude itself and deny an inevitable arena for projection beyond its original area of concern. Perhaps we will have to wait for more mature times before we see a reorientation of NATO's perspective.

It would be a strategic mistake to ignore such a player, which is already the largest regional organization in the world. Actually, by "taking care" of the SCO's development, Western organizations could take care of themselves. The aim should be to be included in an increasingly important chess game, one that will probably determine the political, military and economic development of the Eurasian area in the coming decades.

The field of military cooperation has also gained new prominence in its regional dimension. The 2007 military drills Anti-terror, led by RATS, and the SCO's Peace Mission have had the CSTO as observer. The possibility to establish a security partnership with such a regional military organization (moreover one led by Russia, and whose membership overlaps with that of the SCO) could open the possibility of sharing information or organizing joint military drills in the near future. The development of a mature security and military SCO branch is probably still far away, because it would involve the deepening and widening of cooperation in the military and security field at the same time as promising cooperation in the energy field is being launched. It should also be considered that a strengthened partnership between SCO and CSTO would put

42 Atho Lobjakas, "EU: German presidency's focus on Central Asia, Black Sea, Russia," 19 December 2006, at www.rferl.org.

43 Richard Weitz, "Rinnovare i partenariati dell’Asia Centrale,” Nato Review (Autumn 2006); available at www.nato.int/docu/review/2006/issue3/italian/analysis2.html. 
Russia in a leadership role in security and military matters that could probably meet with Chinese opposition.

Beyond the present spheres of potential SCO development, the organization maintained during its growth and consolidation phases some features that represent its strength. The great novelty of the SCO has since the beginning been its will to put at the core of the organization the common interest of all the members (border issues at the very beginning, then the fight against the "three evil forces," the joint military drills, economic cooperation, and finally joint exploitation of energy resources). All these aims have been pragmatically pursued in the light of a cautious growth process which is at the same time able to pay attention to the interests of outside countries.

If the SCO is able to maintain the correct balance between consolidation and growth, it will surely be one of the main engines of Asian economic development. At this point, Western organizations, namely EU and NATO, should start a dialogue with the SCO, in order not to find themselves of the sidelines of the new great game of Asian growth. 


\section{THE QUARTERLY JOURNAL}

\section{Bibliography}

"China-Russia Communiqué." CEF Quarterly (2005).

"Firmati al Cremlino 21 contratti per un valore di 4 miliardi di dollari." Osservatore Romano(2007).

Abashin, Sergei. "The Transformation of Ethnic Identity in Central Asia: A Case Study of the Uzbeks and Tajiks(link is external)." Russian Regional Perspectives Journal 1, no. 2 (2006): 32-35.

Central Asia: Border Disputes and Conflict Potential In ICG Asia Report., 2002.

China Energy Database. Berkeley, CA: Lawrence Berkeley National Laboratory, 2004.

Crescono gli interessi di Pechino nell'Asia Centrale(link is external)., 2005.

Edgar, Adrienne L.. Identities, Communities and Nations in Central Asia: A Historical Perspective(link is external) Inpresentation given at a panel discussion entitled "Central Asia and Russia: Responses to the 'War on Terrorism'”. Berkeley: University of California, 2001.

Guang, Pan. "The New SCO Observers: Making a Leap Forward in Cautious Augmentation(link is external)."CEF Quarterly-The Journal of the China-Eurasian Forum (2005).

Huasheng, Zhao. Kitaj, Tsentral'naija Azija $i$ Shanhajskaja Organizatsija Sotrudnicestva In Rabocie Materialy. Moskovskij Zentr Karnegi, 2005.

Iran Hopes to Join Shanghai Group This Summer(link is external)., 2006.

Lewis, Finlay. "To Hunter, China is Cause for Alarm." San Diego Union Tribune (2007).

Lobjakas, Atho. EU: German presidency's focus on Central Asia, Black Sea, Russia(link is external)., 2006.

McDermott, Roger. Russia Offers 'Quality' Military Assistance to Kyrgyzstan(link is external)., 2004.

McDermott, Roger. Shanghai Cooperation Organization Takes Significant Step Towards Viability(link is external)., 2003.

Menon, Rajan, and Hendrik Spruyt. The Limits of Neorealism: Understanding Security in Central Asia In Review of International Studies., 1999.

Missiroli, Antonio, and Alessandro Pansa. "La difesa europea." In Il Melangolo., 2007. 
Mont, Malia K. Du. "Cooperation 2003: Style, Substance and Some Surprises(link is external)." CEF Monthly(2003).

Putin, Vladimir. Annual Address to the Federal Assembly(link is external)., 2007.

Russian and Chinese Defense Ministers Praise Joint Military Exercise., 2005.

SCO Needs Military to Fight Regional Terrorist Threat-Official(link is external)., 2006.

Sheives, Kevin. "China and Central Asia's New Energy Relationship: Keeping Things in Perspective(link is external)." CEF Quarterly-The Journal of the China-Eurasia Forum (2005).

Silk Road Studies Weekly Newsletter(link is external)., 2007.

Swanström, Niklas. Chinese Business Interest in Central Asia: A Quest for Dominance(link is external)., 2003.

The Significance of Sino-Russian Military Exercises(link is external)., 2005.

Tolipov, Farkhod. On the Role of the Central Asian Cooperation Organization within the SCO(link is external) InCentral Asia and the Caucasus., 2004.

Trofimov, Dmitri. Shanghai Process: From the 'Five' to the Cooperation Organization. Summing up the 1990s and Looking Ahead In Central Asia and the Caucasus. Sweden: Centre for Social and Political Studies, 2002.

Umarov, Adiljon, and Dmitry Pashkun. "The Prospects for Chinese Influence in Central Asia(link is external)."CEF Quarterly-The Journal of the China-Eurasia Forum (2005).

Weitz, Richard. "Rinnovare i partenariati dell'Asia Centrale(link is external)." Nato Review (2006). 